\title{
Recent Developments in the Application of Inorganic Nanomaterials and Nanosystems for the Protection of Cultural Heritage Organic Artifacts
}

\author{
Toma Fistos 1,2 , Irina Fierascu $1,3, *$ (D) and Radu Claudiu Fierascu $1,2, *$ (D) \\ 1 Emerging Nanotechnologies Group, National Institute for Research \& Development in Chemistry and \\ Petrochemistry_ICECHIM, 060021 Bucharest, Romania; toma.fistos@icechim.ro \\ 2 Department of Science and Engineering of Oxide Materials and Nanomaterials, University Politehnica of \\ Bucharest, 011061 Bucharest, Romania \\ 3 University of Agronomic Sciences and Veterinary Medicine of Bucharest, 011464 Bucharest, Romania \\ * Correspondence: irina.fierascu@icechim.ro (I.F.); fierascu.radu@icechim.ro (R.C.F.)
}

Citation: Fistos, T.; Fierascu, I.; Fierascu, R.C. Recent Developments in the Application of Inorganic Nanomaterials and Nanosystems for the Protection of Cultural Heritage Organic Artifacts. Nanomaterials 2022, 12, 207. https://doi.org/10.3390/ nano12020207

Academic Editor: Maciej Jarosz

Received: 28 December 2021 Accepted: 31 December 2021 Published: 10 January 2022

Publisher's Note: MDPI stays neutral with regard to jurisdictional claims in published maps and institutional affiliations.

Copyright: (C) 2022 by the authors. Licensee MDPI, Basel, Switzerland. This article is an open access article distributed under the terms and conditions of the Creative Commons Attribution (CC BY) license (https:// creativecommons.org/licenses/by/ $4.0 /)$.

\begin{abstract}
Cultural heritage $(\mathrm{CH})$ represents human identity and evidence of the existence and activities that people have left over time. In response to the action of aggressive degrading factors, different materials have been developed and used to protect cultural heritage artifacts. The discovery of optimal materials for this purpose also raises several problems, mainly related to their compatibility with the support material, the most important aspect being that they must preserve their aesthetic characteristics. In this context, the present review paper aims to provide a critical discussion about the possibilities of using different inorganic nanomaterials and recipes for the conservation of cultural heritage objects of organic nature (such as paper, wood, and other support materials). In addition, also are covered different aspect concerning protection mechanisms and application methods as well as future perspectives in this area.
\end{abstract}

Keywords: inorganic nanomaterials; cultural heritage; organic artifacts; protection; conservation

\section{Introduction}

Preservation of cultural heritage represents a forefront issue for researchers all over the world, as cultural heritage artifacts are continuously affected by a series of degradation factors, ranging from environmental aspects to natural or human-induced degradation [1].

In recent years, many scientific areas have been involved in the search for the best solutions to stop the degradation of cultural heritage and to preserve it without irreparably affecting its appearance. The search for an optimal conservation material also needs to consider its compatibility with the support material, as one of the most important properties required for such materials is that they must not alter the aesthetic characteristics of the treated object. Another problem that must be addressed in the development of these materials is the cost, which must be as low and accessible as possible, and the synthesis of these materials as simple as possible without many steps or obtaining many secondary compounds.

Over the last decades, perhaps one of the most important areas of research is represented by the field of nanomaterials and nanotechnology [2]. The term "nanomaterial" may refer to materials composed of single elements, such as metals or carbon, or materials composed of several elements, such as metal oxides or composites, with nano dimensions. The ability to manipulate and control materials at the atomic level and the subsequent understanding of fundamental processes at the nanoscale have led to new challenges. The reason for this is based on the unique and sometimes unexpected physical and chemical properties that are present in nano-level materials such as the increased surface-to-mass ratio, diffusivity, and electrical, optical, and thermal properties. However, the application of 
nanoparticles (NPs) in the field of heritage conservation requires a broader approach combining materials science, petrophysics, microbiology, and cultural heritage conservation with many other scientific disciplines.

The advantages of developing and using materials at the nanoscale include the physicochemical compatibility of inorganic nanomaterials with the support material; the reactivity and penetration capacity of a reinforcing product into the support material and, consequently, its effectiveness are potentially increased when its particle size is reduced to nano-dimensions; an increase in area in relation to the volume and larger surface, improving the electronic and optical properties and the chemical reactivity between the consolidating material and the support material, as a higher proportion of atoms is found on the surface compared to those inside $[3,4]$.

The continuous progress in nanotechnology has led over the last years to the evaluation and proposal of new alternatives for the protection of artifacts of organic nature such as archaeological wood, paper, textile, and leather. Although not as commonly encountered, such as for the conservation of inorganic artifacts, the use of inorganic nanomaterials for the conservation of cultural heritage artifacts of organic nature represents an emerging field of research [5].

In recent years, several review works have been published in the area of cultural heritage preservation using nanomaterials, focusing either on the topical application of selected nanomaterials in the conservation of cultural heritage objects [6], protection of certain types of support materials [7-9], or on the development of antimicrobial agents for cultural heritage application [10]. Although of certain scientific value, these works do not sufficiently cover the area of organic artifact protection and how nanotechnology can contribute to obtaining superior recipes.

In this context, the present review paper aimed to present a critical discussion regarding the possibilities for the use of different materials and recipes for the conservation of cultural heritage objects of organic nature (i.e., paper, wood, and textile). Different aspects about protection mechanisms and application methods are also covered.

\section{Cultural Heritage Objects of an Organic Nature}

Generally speaking, artifact materials can be classified based on standard typologies according to the used materials and manufacturing techniques. One of the main categories is the class of organic artifacts, where the typology includes a variety of objects made from organic materials such as wood, plant fibers, bone, antler, leather, ivory, and shell.

In a particular context, a classification is almost impossible to realize in a correct and complex manner. Baxter describes Read's pioneering paper regarding artifact classification "as one of the best papers of its kind" [11], where a recursive subdivision can be made classifying the objects into obvious groups, and then sub-division of the groups/types can be made based on different variables or qualities of the artefacts studied.

Organic artifacts represent a very large portion of the objects currently found in museums all over the world, being considered extremely vulnerable to deterioration [12], as climate factors, pollution, or microbial attacks can lead to their degradation with specific impacts on each type of object.

The most encountered organic materials found in museum collections are represented by paper artifacts, textiles, leather, paintings on canvas, wood objects, or the so-called "ecofacts", such as ivories or bones, containing both organic and inorganic matter [13].

Figure 1 presents the most encountered organic artifacts, their main composition, and the most encountered degradation phenomena.

In order to understand the potential application of nanomaterials for the protection of organic cultural heritage artifacts, some considerations related to the main factors affecting their longevity are necessary. 


\section{Artifact type}

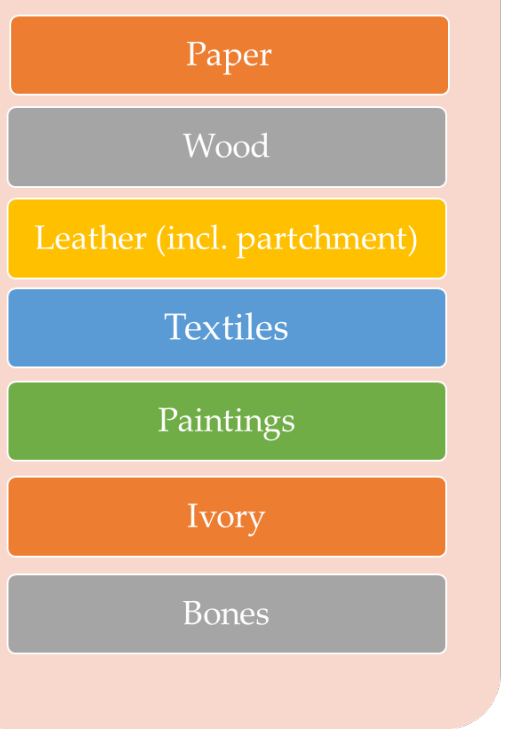

Main composition

Cellulose, hemicellulose, lignin, inorganic

components

Cellulose, hemicellulose, lignin in natural form

Collagen, hyaluronan, proteoglycans

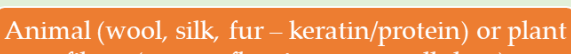

fibers (cotton, flax, jute, etc. - cellulose)

Organic/inorganic dyes and pigments on textile support

Protein, lipids, inorganic part (hydroxyapatite)

Collagen, inorganic part (hydroxyapatite)
Degradation phenomenon

Embrittlement, discolouration

Cracking, surface powdering

Weakening, surface powdering

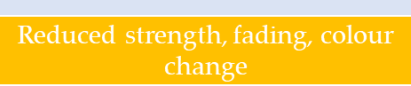

Discolouring, cracking, soiling



Microbial degradation

Figure 1. Main types of organic artifacts and their most encountered degradation phenomena.

All artifacts of organic nature are affected by microbial degradation. Several types of bacteria and fungi have been identified on organic artifacts [14], which can lead to physical and chemical damage as well as aesthetic alterations. Cellulose-based artifacts are commonly affected by fungal species (Ascomycetes, Aspergillus, Paecilomyces, Chrysosporium, Penicillium, Cladosporium, and Eurotium or, in special cases, molds associated with water damage such as Chaetomium, Monoascus, Epicoccum, Trichoderma, and Stachybotrys). These organisms can produce staining of the artifact (i.e., the "foxing" phenomenon), induce embrittlement, or lead to the apparition of strong odors or toxic compounds through an enzymatic action [15]. Leather artifacts (including parchment) are commonly affected by species of the genera Bacillus, Staphylococcus, Pseudomonas, Virgibacillus, and Micromonospora; alkaliphilic bacteria (i.e., Actinobacteria); proteolytic fungi (i.e., Chaetomium and Gymnoascus); mitosporic fungi (i.e., Acremonium, Aspergillus, Aureobasidium, Epicoccum, Trichoderma, and Verticillium) associated with collagen biodeterioration [15]. Wood artifacts are affected by cellulolytic microorganisms (similar to paper artifacts) including cellulase-producing fungi (Trichoderma, Fomitopsis, Aspergillus, Fusarium, and Neurospora), brown rot (Poria, Lenzites, Coniophora, and Tyromyces) and white rot (Phanerochaete, Sporotrichum, and Trametes), anaerobic cellulolytic fungi (Neocallimastix, Piromyces, and Orpinomyces), cellulolytic bacteria (Bacillus, Acinetobacter, Cellulomonas, and Clostridium), rumen bacteria (Fibrobacter, Ruminococcus, Pseudomonas, Proteus, and Staphylococcus), and thermophilic bacteria (Anoxybacillus and Geobacillus) [16]. A special case is represented by waterlogged wood artifacts. Wood artifacts in high-salinity marine environments are rapidly degraded by marine insects, while in low-salinity environments, decay occurs much slower. Moreover, artifacts found in marine sediments are mainly affected by erosion bacteria [17].

Biodegradation of collagen-based artifacts (leather and parchment) involves the chemical oxidative deterioration of amino-acid chains and hydrolytic cleavage of the peptide structure. The most encountered species belong to the genera Bacillus, Staphylococcus, Pseudomonas, Virgibacillus, and Micromonospora; alkaliphilic bacteria (i.e., Actinobacteria); proteolytic fungi (Chaetomium and Gymnoascus); mitosporic fungi (Acremonium, Aspergillus, Aureobasidium, Epicoccum, Trichoderma, and Verticillium). The action of these microbial 
species can lead to the hydrolyzation of collagen fibers and other proteins or produce material discoloration [16].

Textile artifacts are affected by both microorganisms with cellulolytic and proteolytic activities, depending on the nature of the material. Commonly encountered microorganism on textiles of vegetal origin are fungi from the species Alternaria, Aspergillus, Aureobasidium, Chaetomium, Cladosporium, Fusarium, Memnoniella, Mucor, Myrothecium, Paecilomyces, Penicillium, Rhizopus, Stachybotrys, Trichoderma, Trichothecium, and Verticillium and bacteria belonging to the species Arthrobacter, Bacillus, Cellulomonas, Cellvibrio, Clostridium, Cytophaga, Microbispora, Nocardia, Pseudomonas, Sporocytophaga, and Streptomyces. Their action is mainly related to the enzymatic degradation of cellulose. Keratin-based textiles are affected by keratinolytic-inducing microorganisms (fungi-Acremonium, Alternaria, Aspergillus, Cephalothecium, Chaetomium, Chrysosporium, Dematium, Fusarium, Microsporum, Oospora, Penicillium, Rhizopus, Scopulariopsis, Stachybotrys, Trichoderma, Trichophyton, and Ulocladium; bacteria-Alcaligenes, Bacillus, Proteus, Pseudomonas, and Streptomyces), while textile containing mainly protein fibers (such as silk) are affected by microorganisms inducing proteolytic decomposition (fungi-Aspergillus, Chaetomium, Cladosporium, Penicillium, and Rhizopus; bacteria-Aeromonas, Arthrobacter, Bacillus, Chryseomonas, Pseudomonas, Streptomyces, Serratia, and Variovorax) [18].

Ivory and archeological bones are much less exposed to biodeterioration due to the high inorganic content (represented mainly by the hydroxyapatite). The microorganisms encountered are those associated with the degradation of proteins or collagen (as presented for other types of artifacts) or those related to the human skin microbiome or pathogenic bacteria and fungi (Clostridiales and Phialosimplex) or by opportunistic fungi [16].

Besides biodegradation, other deterioration processes are characteristic for each type of materials:

- Cellulose-based artifacts are subjected to acidic degradation of cellulose chains (due to the action of environmental or internal acids), alkaline degradation, photodegradation, and oxidative degradation;

- Collagen-based artifacts, under the action of light, elevated temperatures, humidity, and atmospheric pollutants undergo acidic hydrolysis or oxidative degradation of the functional side groups [19]. Under UV radiation, photodegradation of collagen into a powder form can also be encountered [20];

- Ivory and archaeological bones undergo similar degradation phenomena: while the collagen part of the artifacts can degrade by chemical hydrolysis [21,22], the degradation also affects the inorganic part, which can undergo mineral recrystallization and degradation of mechanical and morphological properties (such as increased porosity).

Nanomaterials can be used to counteract the effects of both biodeterioration as well as chemical or photodegradation, or it can even be used for the consolidation of the inorganic part of mixed artifacts. This can be achieved through harnessing their well-known properties (antimicrobial, UV protection, etc.) and selection of nanoparticles compatible with the support material. Moreover, some nanoparticles can react with the support material, leading to the formation of other compounds that can contribute to the consolidation of the artifacts.

\section{Inorganic Nanomaterials for the Protection of Paper Artifacts}

Paper artifacts represent one of the most fragile and, at the same time, widely spread cellulose-based objects. Compared with other similar objects, such as, for example, historical wood, paper artifacts possess particularities that make them more exposed to degradation including the treatment applied for paper manufacturing and their physical properties as well as the presence of inks and pigments on their surface. All these factors can lead to an accelerated degradation of paper artifacts for which the development of treatment methods represent an important research topic [23]. 
Considering the degradation processes commonly encountered in paper artifacts, the main application of nanomaterials as consolidants and preventive treatments are presented in Table 1.

Table 1. Application of inorganic nanomaterials for the treatment of historical paper artifacts (references presented in chronological order).

\begin{tabular}{|c|c|c|c|}
\hline $\begin{array}{l}\text { Nanomaterial } \\
\text { Characteristics }\end{array}$ & Application Method & Obtained Results & References \\
\hline $\mathrm{MgO}$, nanorods (<100 nm) & $\begin{array}{c}\text { Immersion of acidified paper } \\
\text { in nanoparticle solution } \\
\text { in propanol }\end{array}$ & $\begin{array}{c}\text { Neutralization of a part of the sulfuric acid } \\
\text { molecules. Treatment protected against } \\
\text { hydrolytic degradation and } \\
\text { depolymerization, regardless of the presence } \\
\text { of gall ink. Deacidification led to an } \\
\text { imperceptible increase in the brightness } \\
\text { and yellowing. }\end{array}$ & [24] \\
\hline $\begin{array}{c}\mathrm{Ca}(\mathrm{OH})_{2}, \text { solvothermal } \\
\text { method, dispersed in } \\
n \text {-propanol in gelatin solution }\end{array}$ & $\begin{array}{l}\text { Brush application of solution } \\
\text { on paper containing gall ink } \\
\text { (both simulated and } \\
\text { real artifacts) }\end{array}$ & $\begin{array}{l}\text { Simulated artifacts: significant differences in } \\
\text { the cellulose degree of polymerization } \\
\text { between treated and untreated samples were } \\
\text { observed upon artificial aging. } \mathrm{pH} \\
\text { preservation at } 9 \text { after accelerated aging. } \\
\text { Historical paper: } \mathrm{pH} \text { preservation at } 6.5 \text {. }\end{array}$ & [25] \\
\hline $\begin{array}{l}\mathrm{ZnO}, 150 \mathrm{~nm} \text {, dispersed in } \\
\text { ethanol with } \\
\text { hydroxypropyl cellulose }\end{array}$ & $\begin{array}{l}\text { Spray coating of different } \\
\text { types of paper }\end{array}$ & $\begin{array}{l}\text { Protection of paper against UV radiation, } \\
\text { fungi, and bacteria. }\end{array}$ & [26] \\
\hline $\begin{array}{l}\mathrm{Ca}(\mathrm{OH})_{2} \text {, solvothermal } \\
\text { method, dispersed } \\
\text { in cyclohexane }\end{array}$ & $\begin{array}{l}\text { Airbrush application on acidic } \\
\text { paper and on historical } \\
\text { paper artwork }\end{array}$ & $\begin{array}{l}\text { Acidic paper: resilience to aging, lower } \\
\text { cellulose depolymerization, and less } \\
\text { color changes. } \\
\text { Paper artwork: safeguarding of the original } \\
\text { shape and topography of the support. }\end{array}$ & [27] \\
\hline $\begin{array}{l}\mathrm{Ca}(\mathrm{OH})_{2} \text {, dispersed in } \\
\text { 2-propanol }\end{array}$ & Soaking in the NP solution & $\begin{array}{l}\text { Stabilization of the } \mathrm{pH} \text { values }(7-8.2) 1 \text { year } \\
\text { after treatment and restoration of the } \\
\text { alkaline reserve. }\end{array}$ & [28] \\
\hline $\begin{array}{c}\mathrm{Ag} \text {, in combination with } \\
\text { carboxymethyl cellulose, } \\
\text { chitosan, soya beans flour, } \\
\text { BEVA } 371\end{array}$ & $\begin{array}{l}\text { Direct formation on the } \\
\text { surface of the paper, followed } \\
\text { by consolidant application on } \\
\text { cotton linter and an } 1887 \\
\text { book sample }\end{array}$ & $\begin{array}{l}\text { Antimicrobial effect against Staphylococcus } \\
\text { aureus, Aspergillus niger, Candida albicans, and } \\
\text { Pseudomonas aeruginosa and improvement in } \\
\text { the mechanical properties with a detrimental } \\
\text { effect (color change) in combination with } \\
\text { CMC and chitosan. }\end{array}$ & [29] \\
\hline $\begin{array}{l}\mathrm{TiO}_{2}, 25 \mathrm{~nm} \text {, dispersed in } \\
\text { carboxymethyl cellulose with } \\
\text { and without chitosan }\end{array}$ & $\begin{array}{l}\text { Brush coating of Whatman } \\
\text { filter paper }\end{array}$ & $\begin{array}{l}\text { Developed adhesive led to protection against } \\
\text { Aspergillus flavus and } A \text {. niger, increasing the } \\
\text { tensile strength of the paper with a slight } \\
\text { reduction in } \mathrm{pH} \text {; protection } \\
\text { against yellowing. }\end{array}$ & [30] \\
\hline $\begin{array}{l}\text { MgO-oleic acid in } \\
\text { cyclohexane }\end{array}$ & $\begin{array}{l}\text { Impregnation and immersion } \\
\text { of different types of paper }\end{array}$ & $\begin{array}{l}\text { Reduction in the surface } \mathrm{pH} \text { of all types of } \\
\text { acidic papers to } \sim 8.0 \text { without affecting the } \\
\text { tensile strengths. After accelerated aging } \\
\text { tests, surface } \mathrm{pH} \text { and tensile strength values } \\
\text { of treated samples were greater than the } \\
\text { untreated ones; application in the inter-layer } \\
\text { crevice and on the surface led to a change in } \\
\text { the hydrophobicity of the papers (from } \\
\text { hydrophilic to hydrophobic). }\end{array}$ & [31] \\
\hline
\end{tabular}


Table 1. Cont.

Nanomaterial

Characteristics

$\mathrm{Mg}(\mathrm{OH})_{2}(<100 \mathrm{~nm})$ in trimethylsilyl cellulose
Obtained Results
Application Method

References

The treatment reduced water wettability and increased mechanical strength of the paper.

Dip coating of paper samples Mechanical properties (i.e., strength and

elasticity) were improved with an increased number of coating steps

The treatment increased the $\mathrm{pH}$ value (from

2.5 to 10.5 for old paper), alkaline reserve (up

to $372 \mathrm{mmol} / \mathrm{kg}$ for old paper), and

mechanical properties (up to 6 GPa for

Young's modulus for old paper).

synthesized nanosheets) in and old paper samples

alcoholic aqueous solution

Brush coating on accelerated aged cotton and wood paper

Preservation of tensile strength and elongation rate upon accelerated aging.

oaded in methyl methacrylate

hydroxyethyl methacrylate
$\mathrm{ZnO}$, obtained by chemical route, with cellulose nanocrystals, $50 \mathrm{~nm}$
In situ coating of newspaper
Increased color stability of the paper coated; antimicrobial effect of the nanocomposite against fungi (A. niger, A. versicolor, Rhizopus nigricans, Saccharomycetes, and Mucor) and

bacteria (Staphylococcus aureus and Escherichia coli).

\section{Biosynthesized spherical Ag (26-62 nm) and $\mathrm{ZnO}(8-23 \mathrm{~nm})$}

Old book paper
$\mathrm{MgO}$ (sol-gel method), $12 \mathrm{~nm} \quad \begin{gathered}\text { Impregnation of XVIIIth } \\ \text { century paper with } \\ \text { NP solution }\end{gathered}$

Spray deposition of nanoparticles on paper inoculated with $A$. niger from old book paper
$2 \mathrm{mM}$ NP solutions prevented

fungal biodeterioration and enhanced tensile strength.
$10 \mathrm{mg} / \mathrm{mL}$ dispersion of MgO NPs provided complete inhibition of the Trichoderma reesei, A. niger, and Cladosporium cladosporioides fungal strains, avoiding color changes. Inhibited $A$. niger and T. reesei cellulase enzymes.
Deposition of nanoparticles on paper inoculated with

Biosynthesized Ag and $\mathrm{ZnO}$ nanoparticles

Bacillus subtilis and Penicllium chrysogenum strains on a XVIIth century manuscript

Spray coating on 1954 wheat straw pulp paper, followed by the addition of saturated $\mathrm{Ca}(\mathrm{OH})_{2}$ solution
$1 \mathrm{mM}$ AgNP and $2 \mathrm{mM}$ ZnO-NPs led to $100 \%$ microbial inhibition. Treated paper exhibited a slight color change and a similar structural analysis as the original paper.

$\mathrm{pH}$ value increased to 7.5-9.0 and alkali storage to $220 \mathrm{mmol} / \mathrm{kg}$. Tensile strength

$80 \%$. Color difference was negligible.

The treatment provided good antimicrobial

(A. niger) and anti-aging performances.

Increased and stabilized the paper $\mathrm{pH}$ (no

significant decrease during aging); enhanced the paper's mechanical properties.

The treatment neutralized the acidic functions of the papers, increased the alkaline reserve, and increased the mechanical strength, even compared to the

classical spraying method. and folding degree increased by $28.05 \%$ and
Non-aqueous coating of naturally aged acidic paper including different pigments $\mathrm{nm}$ ) dispersed in in subcritica

1,1,1,2-tetrafluoroethane
80 year old paper washed in NP solution 
Table 1. Cont.

Nanomaterial

Characteristics solutions, $\mathrm{Ca}(\mathrm{OH})_{2}$ commercial products
Application Method

Obtained Results

All treatments led to alkaline $\mathrm{pH}$ values above 9 for commercial products and below 9 for carbonate; $\mathrm{pH}$ values should be under 9 , as undesirable reactions could appear for lignocellulosic papers. Sufficient alkaline reserve (corresponding to the ISO/TS 18344/2016 standard). Less color change induced by carbonate compared with commercial products. solution followed by accelerated aging

\begin{tabular}{cc}
\hline $\begin{array}{c}\text { Nano-wollastonite }\left(\mathrm{CaSiO}_{3}\right), \\
30-110 \mathrm{~nm} \text {, in gel form, } \\
\text { commercial }\end{array}$ & $\begin{array}{c}\text { Impregnation of a } 75 \text { year } \\
\text { old book }\end{array}$ \\
$\begin{array}{c}\mathrm{Ca}(\mathrm{OH})_{2} \text { (hexagonal platelets, } \\
20-30 \mathrm{~nm} \text { in thickness, } 140 \mathrm{~nm} \\
\text { in diameter) and } \mathrm{CaCO}_{3}(70 \\
\mathrm{nm}) \text { by solvothermal method }\end{array}$ & $\begin{array}{c}\text { Brush coating of nanoparticles } \\
\text { dispersed in oleic acid-grafted } \\
\text { cellulose nanocrystals on } \\
\text { acidified and aged paper }\end{array}$ \\
\hline
\end{tabular}

Nano-wollastonite $\left(\mathrm{CaSiO}_{3}\right)$, $\mathrm{nm}$, in gel form commercia

Immersion in nanoparticle
Significant hindering of $A$. niger growth at $20 \%$ and decreased permeability.

References

The treatment proved to be highly effective in the strengthening and deacidification of

AgNPs (synthesized by chemical reduction, 8-10 $\mathrm{nm}) /$ nanocrystalline cellulose composites
Brush application on paper samples

\section{[43]}

Ultrasonic atomization deposition on paper samples

$\mathrm{Na}_{2} \mathrm{CO}_{3}$ solution and styren acrylic latex composite acidic and degraded paper, without significant alterations in the visual aspect of samples.

The treatment enhanced the plastic properties of the paper, increasing inter-fiber interactions (leading to higher tensile strain resistance). Good biocidal activity against $A$.

$$
\begin{aligned}
& \text { niger, while not affecting } \\
& \text { aesthetic appearance. }
\end{aligned}
$$

$\mathrm{Na}_{2} \mathrm{CO}_{3}$ latex led to a $\mathrm{pH}$ higher than 7 , only

slight color change. Breaking length and the

At $10 \%$ nanocomposite, treated paper retains a neutral $\mathrm{pH}$ value on exposure

to acidic atmosphere. The tensile properties of the paper were improved after impregnation. Colorimetric properties and

$$
\text { after treatment. }
$$

$\mathrm{MgO}$ in halloysite nanotubes in carboxymethyl cellulose
Impregnation of paper samples in nanocomposite solution tear index were increased. Ink and

handwriting were not diffused or smudged.

$$
\text { the writing quality were not modified }
$$

The AgNPs treatment proved to be less efficient disinfectant, compared with the ethylene oxide, against Bacillus subtilis, Streptomyces sp., A. versicolor and T. viride. AgNPs had less impact on the photographic
AgNPs (10-80 nm) in aqueous solution
Disinfection in a misting paper models
chamber of photographic

models' material properties (including color
change and mechanical properties)

models' material properties (including colc
change and mechanical properties)
Deacidification can be achieved by providing alkaline reservoirs; two main issues should be addressed when applying this strategy:

- $\quad$ Formulation of the deacidification solution, as the presence of some surfactants/stabilizers could lead to a reduction in nanoparticle reactivity, creating a too alkaline environment that could result in the alkaline depolymerization process [31];

- Compatibility of the proposed recipes with other elements present on the paper artifacts (such as inks, dyes, or pigments) [23].

The most important aspect regarding paper conservation is related to its deacidification. As already mentioned, acidification of cellulose-based objects in general (and of paper artifacts in special) leads to cellulose depolymerization (Figure 2); for paper objects, this 
has dramatic consequences, both in mechanical properties (the papers becoming brittle) and in the aesthetic characteristics (by darkening) [23,31].

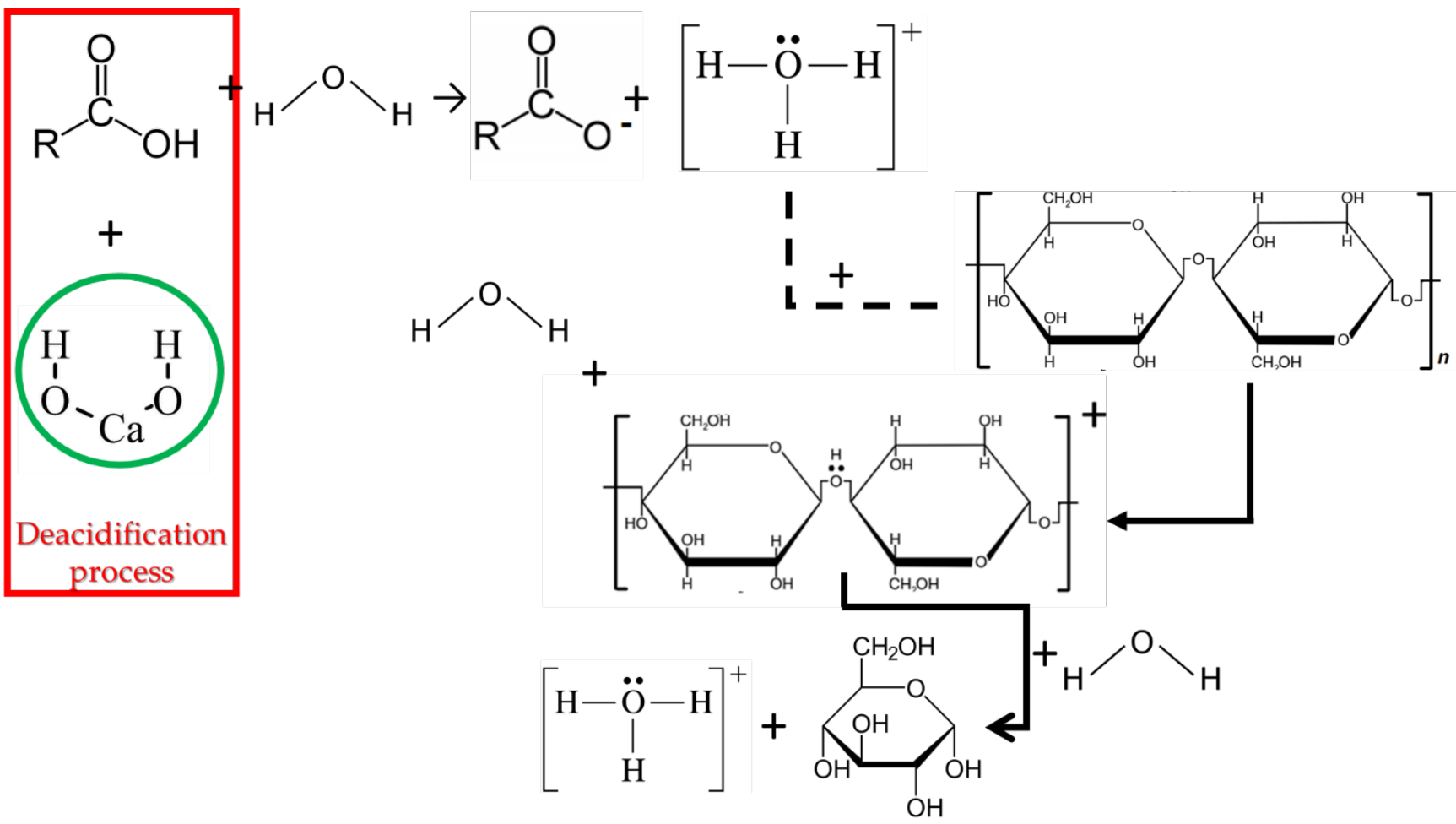

Figure 2. Acid degradation of cellulose, one of the most important degradation processes of paper artifacts, and the deacidification process (red square) realized by the addition of an alkaline reservoir (exemplified by calcium hydroxide).

In general, the deacidification of paper using metallic oxides occurs via the chemical interaction between the nanoparticles and acidic substances in the presence of $\mathrm{CO}_{2}$ by the conversion of oxides to hydroxides and carbonates [49]; metallic hydroxide act by reaction with atmospheric $\mathrm{CO}_{2}$, resulting in carbonate deposition (although they have as a main drawback the tendency to have values significantly higher than neutral) [50], while the carbonates acts as an "alkaline reserve buffer", being able to neutralize the acidic species adsorbed onto the paper, or in situ generated, until they are exhausted [50].

Multiple alkaline solutions are presented in the literature (detailed in Table 1), mostly based on $\mathrm{Mg}$ or Ca oxides and hydroxides, as single components or incorporated in different treatment systems. As several commercial products are available on the market [37], we consider that the exhaustive presentation of these compounds is not necessary. The main conclusion that can be drawn from these studies is related to the possibilities to enhance these solutions, mainly in the nanomaterial's synthesis stage. As emerging from the literature, the most promising morphology is represented by the nanosheets' morphology, which allows for not only the development of the alkaline reserve, but it also covers the paper fibers, acting as lamination sheet, as a first line of defense against acid attack from environmental sources [33]. Calcium and sodium carbonates are also common apparition in literature studies as sources of alkaline reserve [42,46].

As an example of a less commonly used nanomaterial, Nemoykina et al. [40] presented the application of magnesium oxyhydroxide not only for the deacidification of an old lowquality book but also for its preservation. The developed lamellar nanostructures covered the paper fibers, strengthening them by surface bonding ( $25 \%$ increase), the samples becoming more resistant to aging. Even more, the deacidification treatment led to $\mathrm{pH}$ stabilization, as no significant decrease was observed upon aging and to a $10 \%$ increase in whiteness. 
Application of nanomaterials with known antimicrobial properties can provide protection against the biodeterioration induced by fungi or bacteria. This approach was presented by Jia et al. [35], who proposed the application of $\mathrm{ZnO} /$ nanocellulose composites as potent antimicrobial agents in the protection of paper artifacts. Their results showed that the nanocomposite not only provides a superior protection against biodeterioration, but it also possesses UV adsorption properties, inducing UV resistance as well as superior thermal resistance.

A particular case (not presented in Table 1) is represented by the study of Hassan et al. [51], who applied $\mathrm{ZnO}$ (spherical, $21 \mathrm{~nm}$ ) in hydroxypropyl cellulose for the reinforcement of papyrus samples. Although not technically a study performed on paper samples, we chose to present the study in this chapter, as the characteristics of papyrus are closely related to those of paper. The treatment led to a final $\mathrm{pH}$ of 7.08 (after artificial aging), a desired $\mathrm{pH}$ value for the conservation purposes, and to a conservation of tensile strength and elongation after the aging process.

A schematic representation of the potential application of nanomaterials for the preservation of paper artifacts is presented in Figure 3.

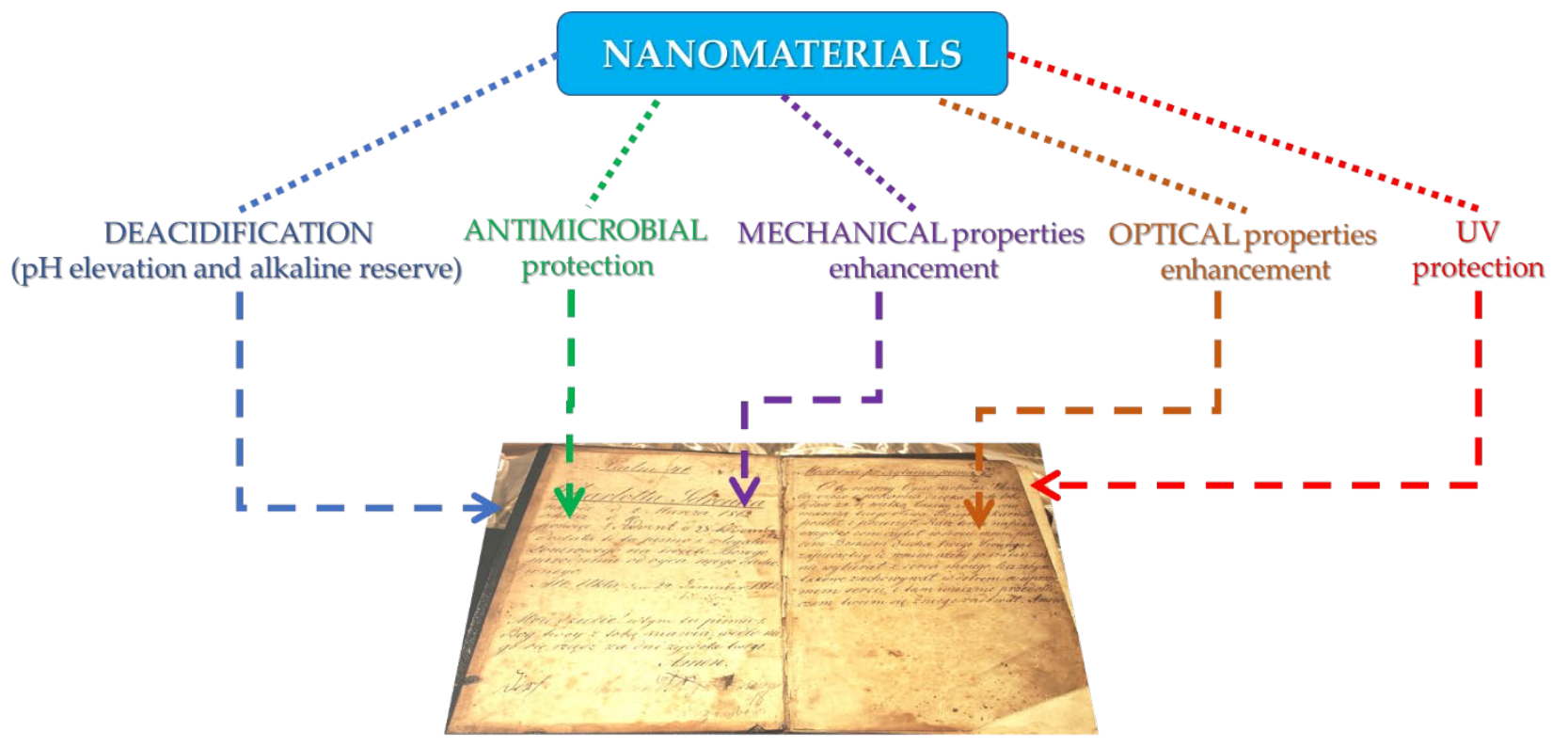

Figure 3. Application of nanomaterials for the protection of paper artifacts.

\section{Inorganic Nanomaterials for the Protection of Historical Wood}

Wood represents a widely encountered material in the area of cultural heritage. Whether we are speaking of vernacular constructions, art objects, or ships, wood with historical value is encountered all over the world. Most of these objects are either part of outdoor constructions or waterlogged wood, as such being exposed to different environmental conditions which accelerates their decay. The treatment of degradation was traditionally performed by resection of the affected parts, followed by their replacement with other materials. This approach has currently been replaced with a more modern one, involving the preservation of the original material through consolidation as well as preventive treatment [52]. A common method for the treatment of historical wood involves the use of organic compounds (natural resins and bio-based or synthetic polymers), as recently presented by our group [53]. However, over the last years, new alternative treatments have been proposed. Among these consolidants and preventive treatments, several inorganic compounds can be identified in the literature (Table 2). 
Table 2. Application of inorganic nanomaterials for the treatment of historical wood (references presented in chronological order).

\begin{tabular}{|c|c|c|c|}
\hline $\begin{array}{l}\text { Nanomaterial } \\
\text { Characteristics }\end{array}$ & Application Method & Obtained Results & References \\
\hline $\begin{array}{c}\mathrm{Ca}(\mathrm{OH})_{2} \text { hexagonal particles, } \\
180 \mathrm{~nm}\end{array}$ & $\begin{array}{c}\text { Vacuum suction of NP } \\
\text { solution into waterlogged } \\
\text { archaeological wood (Vasa } \\
\text { ship samples) }\end{array}$ & $\begin{array}{l}\text { Deacidification of the treated samples, to } \\
\text { neutral values, up to } 8 \text {. }\end{array}$ & [54] \\
\hline $\begin{array}{l}\mathrm{TiO}_{2}(10-15 \mathrm{~nm}) \text { and } \mathrm{ZnO}_{2} \\
(10-30 \mathrm{~nm}) \text { embedded in } \\
\text { polyvinyl butyral }\end{array}$ & $\begin{array}{l}\text { Treatment under vacuum of } \\
\text { poplar wood }\end{array}$ & $\begin{array}{l}\text { Antimicrobial protection against Trametes } \\
\text { versicolor (white rot fungi) at } 1 \% \text { under light, } \\
\text { color stability, and lignin degradation } \\
\text { prevention. }\end{array}$ & [55] \\
\hline $\mathrm{SrCO}_{3}, 50 \mathrm{~nm}$ & $\begin{array}{l}\text { Immersion and surface } \\
\text { brushing of nanoparticle } \\
\text { solution of oak waterlogged } \\
\text { wood (Mary Rose ship) }\end{array}$ & $\begin{array}{l}\text { Neutralization of sulfur-containing acidic } \\
\text { compounds, with the formation of insoluble } \\
\text { strontium sulfate; } \mathrm{pH} \text { increased from } 3 \text { to up } \\
\text { to } 5 .\end{array}$ & [56] \\
\hline $\begin{array}{l}\mathrm{ZnO},<100 \mathrm{~nm}, \mathrm{~B}_{2} \mathrm{O}_{3},<30 \mathrm{~nm}, \\
\mathrm{CuO}, 23-37 \mathrm{~nm}, \mathrm{TiO}_{2} \\
<25 \mathrm{~nm}, \mathrm{CeO}_{2},<25 \mathrm{~nm}, \mathrm{SnO}_{2} \\
<100 \mathrm{~nm}, \text { commercial }\end{array}$ & $\begin{array}{l}\text { Vacuum-treated sapwood } \\
\text { portions of Scots pine, } \\
\text { according to the BS EN } 113 \\
\text { standard test } \\
\text { method }\end{array}$ & $\begin{array}{c}\mathrm{CuO} \text { and } \mathrm{SnO}_{2} \text { inhibited fungal decay by } T \text {. } \\
\text { versicolor in weathered and unweathered } \\
\text { specimens; all materials prevented decay by } \\
\text { Gloeophyllum trabeum except for the } \\
\mathrm{B}_{2} \mathrm{O}_{3} \text {-treated and weathered sample. } \mathrm{CuO} \\
\text { and } \mathrm{B}_{2} \mathrm{O}_{3} \text { inhibited termite feeding. } \mathrm{ZnO} \text { and } \\
\mathrm{CeO}_{2} \text { caused moderate termite resistance. } \\
\mathrm{ZnO} \text { and } \mathrm{B}_{2} \mathrm{O}_{3} \text { inhibited mold growth. }\end{array}$ & [57] \\
\hline
\end{tabular}

Direct dipping of nanocomposite solution for consolidation of waterlogged archaeological wood

$\mathrm{Ca}(\mathrm{OH})_{2}$ dispersed in ethanol $(5 \mathrm{~g} / \mathrm{L})$ (softwood and hardwood), alum-treated archaeological wood (Oseberg find), and sound oak
$\mathrm{pH}$ increased (2-3 units); on degraded samples with very small amounts of cellulose, a $\mathrm{pH}$ of 5.5 was reached; stabilization after 1 month.
Nanomaterials used in combination with the consolidant slowed fungal degradation and did not inhibit surface mold growth; improved water resistance. Consolidant treatment reduced nanoparticle leaching.
$\mathrm{ZnO},<100 \mathrm{~nm}, \mathrm{~B}_{2} \mathrm{O}_{3},<30 \mathrm{~nm}$

$\mathrm{CuO}, 23-37 \mathrm{~nm}, \mathrm{TiO}_{2},<25 \mathrm{~nm}$,

$\mathrm{CeO}_{2},<25 \mathrm{~nm}, \mathrm{SnO}_{2},<100 \mathrm{~nm}$, commercial, combined with

$\mathrm{TiO}_{2} / \mathrm{Ce}$ xerogel
Vacuum-treated sapwood

portions of Scots pine, according to the BS EN 113 standard test method
Paraloid B72 consolidant

Soaking of Norway spruce wood followed by evaluation of antifungal efficiency ( $G$. trabeum, Rhodonia placenta, and Coniophora puteana, acc. EN 113 standard) and mechanical assays
$\mathrm{Ca}(\mathrm{OH})_{2}$ encapsulated in halloysite nanotubes in PEG 1500 solution
Immersion in nanocomposite solution for consolidation of waterlogged archaeological wood (Chretienne C ship)
The treatment led to increased resistance against brown rot decay, maintaining the mechanical properties.

\section{[60]}

Mechanical consolidation (increase in the elastic modulus and stress at the breaking point) and deacidification of the treated samples ( $\mathrm{pH}=7.612$ months after treatment).

Stopping the wood weathering process (increased surface hardness, increased hydroscopic stability).
Brushing of young and aged hazelnut wood
Improved pinewood decay resistance against
Impregnation of pine tree samples white rot fungi (Ganoderma applanatum)

above $2.5 \%$ content without affecting the hardness results. 
Table 2. Cont.

\begin{tabular}{|c|c|c|c|}
\hline $\begin{array}{l}\text { Nanomaterial } \\
\text { Characteristics }\end{array}$ & Application Method & Obtained Results & References \\
\hline $\begin{array}{l}\mathrm{ZnO}, 29 \mathrm{~nm} \text {, in polyvinyl } \\
\text { butyral matrix }\end{array}$ & $\begin{array}{l}\text { Immersion on consolidant } \\
\text { solution of historic wood and } \\
\text { oriental plane samples }\end{array}$ & $\begin{array}{l}\mathrm{ZnO} \text { addition lowered the degradation rate } \\
\text { at accelerated aging and decreased water } \\
\text { penetration and wettability. Optimum } \\
\text { concentration was } 1 \mathrm{wt} \% \mathrm{ZnO} \text {. }\end{array}$ & {$[64]$} \\
\hline $\begin{array}{l}\mathrm{CeO}_{2} \text { embedded in } \\
\text { biopolymers (chitosan or } \\
\text { cationic starch) }\end{array}$ & $\begin{array}{l}\text { Immersion in NP/biopolymer } \\
\text { solution of spruce wood }\end{array}$ & $\begin{array}{l}\text { Reducing UV-related color changes } \\
\text { (especially yellowing). }\end{array}$ & {$[65]$} \\
\hline $\begin{array}{l}\mathrm{ZnO}_{2} \text { (spherical, } 8-15 \mathrm{~nm} \text {, } \\
\text { solvothermal method) and } \\
\mathrm{TiO}_{2} \text { (under } 25 \mathrm{~nm}, \\
\text { hydrothermal method) } \\
\text { embedded in polymer }\end{array}$ & $\begin{array}{l}\text { Immersion in NP/polymer } \\
\text { solutions of cedar and } \\
\text { sycamore woods }\end{array}$ & $\begin{array}{l}\text { Increased mechanical properties (increased } \\
\text { bending and compression resistances). }\end{array}$ & {$[66]$} \\
\hline $\begin{array}{l}\mathrm{Ca}(\mathrm{OH})_{2} \text { - hexagonal lamellas, } \\
10 \mathrm{~nm}, \mathrm{Mg}(\mathrm{OH})_{2} \text { - hexagonal } \\
\text { lamellas, under } 10 \mathrm{~nm}\end{array}$ & $\begin{array}{l}\text { Immersion on NP solution for } \\
\text { preventive and curative } \\
\text { treatment of waterlogged } \\
\text { wood (Gallo-Roman wreck) }\end{array}$ & $\begin{array}{c}\text { Deacidification of the treated samples to } \\
\text { neutral } \mathrm{pH} \text { values. }\end{array}$ & {$[67]$} \\
\hline $\begin{array}{c}\mathrm{Al}_{2}\left(\mathrm{SO}_{4}\right)_{3}, \mathrm{CuSO}_{4} \cdot 5 \mathrm{H}_{2} \mathrm{O} \\
\mathrm{H}_{3} \mathrm{BO}_{3} \text { introduced into } \\
\mathrm{H}_{3} \mathrm{PO}_{4}\end{array}$ & Treatment of sapwood & $\begin{array}{l}\text { Efficient mildew resistance after } 28 \text { days of } \\
\text { exposure to } A \text {. niger and } T \text {. viride. }\end{array}$ & [68] \\
\hline $\begin{array}{l}\text { Halloysite } \\
\text { nanotubes/pluronic } \\
\text { nanocomposites }\end{array}$ & $\begin{array}{l}\text { Treatment of } \\
\text { waterlogged wood }\end{array}$ & $\begin{array}{l}\text { Nanotubes added reaching the internal part } \\
\text { of the wood (consolidating not only the } \\
\text { surface) through the lignin channels. }\end{array}$ & [69] \\
\hline $\begin{array}{l}\text { Halloysite nanotubes in } \\
\text { molten paraffin wax }\end{array}$ & $\begin{array}{l}\text { Immersion on composite } \\
\text { solution of waterlogged wood }\end{array}$ & $\begin{array}{l}\text { Overall, improvement in the mechanical } \\
\text { properties; Young's modulus / stress at } \\
\text { breaking increased, the elongation at break } \\
\text { decreased, in the absence of side effects. }\end{array}$ & {$[70]$} \\
\hline $\begin{array}{c}\mathrm{ZnO}(30-110 \mathrm{~nm}), \mathrm{ZrO}_{2} \\
\text { (90-230 nm), functionalized } \\
\text { with 3- } \\
\text { glycidoxypropyltrimethoxysilane } \\
\text { (GPTMS) in } \\
\text { shellac-based varnishes }\end{array}$ & $\begin{array}{l}\text { Brushing of maple } \\
\text { wood samples }\end{array}$ & $\begin{array}{l}\text { Increased resistance to alcoholic media; no } \\
\text { negative effect on the chromatic properties of } \\
\text { the coating; improved water-repellence } \\
\text { behavior; } \mathrm{ZrO}_{2} \text { varnish increased resistance } \\
\text { to scratches; } \mathrm{ZnO} \text { varnish increased } \\
\text { resistance to UV aging and enhanced } \\
\text { resistance to mold growth. }\end{array}$ & {$[71]$} \\
\hline
\end{tabular}

The use of nanoparticles in the area of historical wood preservation is focused on several main applications: consolidation of the wood samples (influencing the mechanical properties), deacidification (including neutralization of sulfur-containing acidic compounds), and antimicrobial protection.

For example, Cavallaro et al. [61] presented the deacidifying consolidation of waterlogged archaeological woods using aqueous dispersions of polyethylene glycol (PEG) 1500 and halloysite nanotubes containing calcium hydroxide. By incorporating the calcium hydroxide into the halloysite nanotubes, a prolonged release was achieved, extending its deacidification action, recording a $\mathrm{pH}$ of 7.6 even 12 months after the treatment. Moreover, addition of the modified nanotubes to the polymer led to a remarkable increase in the mechanical performances in terms of flexural strength and rigidity compared with the pure PEG.

Andriulo et al. [58] applied via direct dipping of calcium hydroxide nanoparticles obtained by the solvothermal method for the consolidation of waterlogged archaeological wood (softwood and hardwood), alum-treated archaeological wood (belonging to the Oseberg find), and sound oak. Their results revealed a $\mathrm{pH}$ increase from 2-3 to 5.5 for the waterlogged wood, an increase that was stable for over 1 month after treatment. 
Moreover, the treatment proved to be effective also in the case of very degraded waterlogged wood (for which the cellulose phase is almost completely destroyed, and a very high alum content is recorded).

Another example of the application of inorganic nanoparticles is represented by the study by Poggi et al. [54], which used calcium hydroxide nanoparticles obtained by solvothermal reaction for the deacidification of degraded waterlogged wood (oak wood specimens from original Vasa timber). By developing a specific vacuum treatment, the particles were used to treat the wood specimens, the $\mathrm{pH}$ and differential thermal fravimetric (DTG) measurements revealed that NP dispersions penetrated the wood, leading to its deacidification and the prevention of mechanical properties loss.

Nanoparticles with well-known antimicrobial properties can be easily incorporated into polymeric matrixes or directly deposited onto the wood artifacts, allowing for the slow release of the NPs and a prolonged antimicrobial action as demonstrated by Harandi et al. [55], Ion et al. [62], and Yves et al. [68]. The application of UV adsorbers (such as $\mathrm{CeO}_{2}$ or $\mathrm{ZnO}$ ) can represent a good solution for avoiding UV-related color changes in wood, especially the yellowing phenomenon (caused by the photodegradation of lignin and amorphous polysaccharides [7]) as proposed by Janesch et al. [65] and Weththimuni et al. [71]. Guo et al. [60] also demonstrated the application of $\mathrm{TiO}_{2} / \mathrm{Ce}$ nanomaterials, in the form of xerogels for the protection of Norway spruce wood samples against brown rot fungi (Gloeophyllum trabeum, Rhodonia placenta, and Coniophora puteana). The results revealed good antifungal protection but also the lack of any negative influence of the treatment on the mechanical properties (Brinell hardness test). The authors assigned the protective effect of the treatment to three main factors: (i) shielding of the cell wall by formation of a protective layer on the inner lumen surface; (ii) blocking of the micro/nanopores of the wood; (iii) a radical scavenging function.

The most important applications of inorganic nanoparticles in the protection of historical wood are schematically presented in Figure 4.

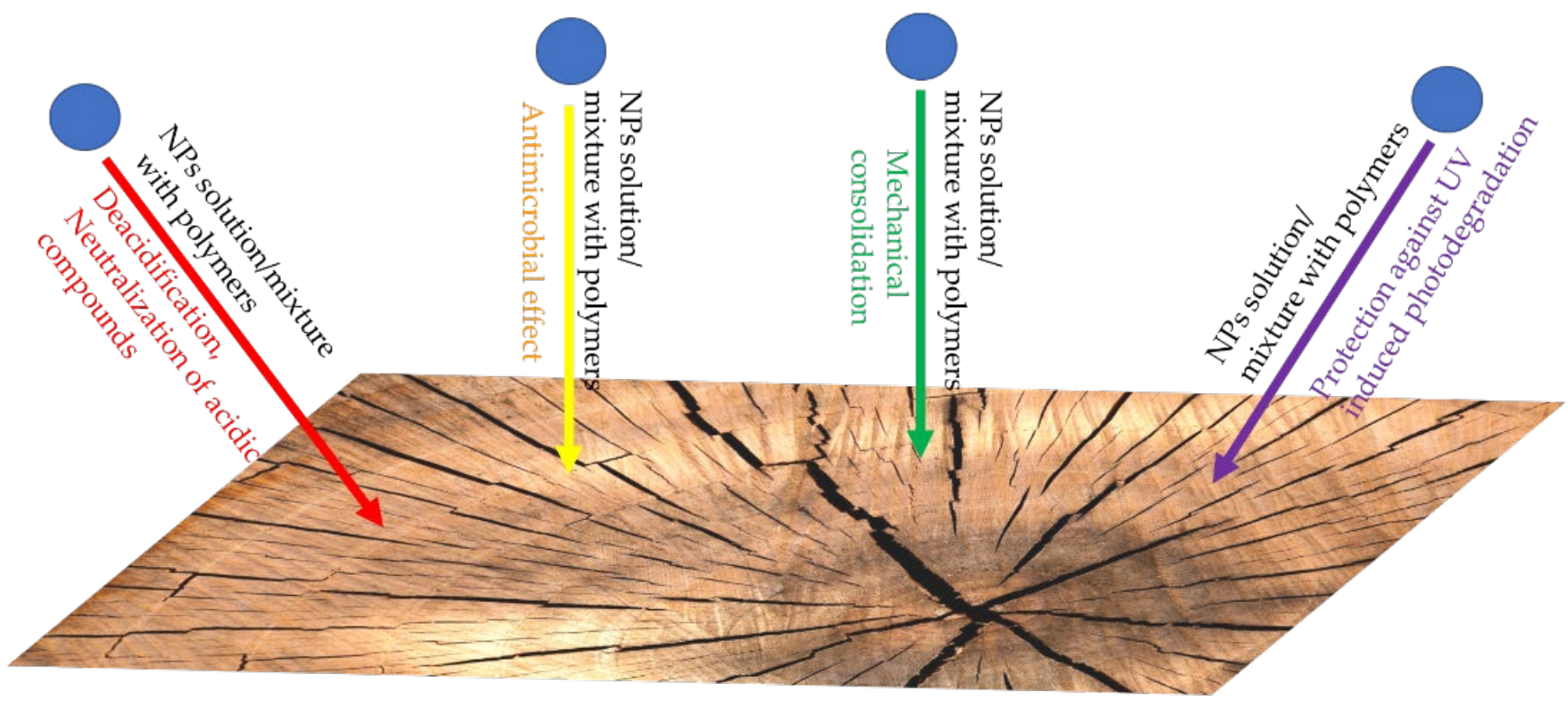

Figure 4. Potential application of nanomaterials for historical wood protection.

\section{Inorganic Nanomaterials for the Protection of Other Types of Cultural Heritage Artifacts of an Organic Nature}

Although not as commonly encountered as in the case of paper and wood protection, nanomaterials also find application in the protection of other types of cultural heritage artifacts of organic nature. Representative examples for these applications are presented 
in Table 3 and Figure 5. In selecting the applications to be presented in Table 3, the origin of the artifacts was considered, not their present-day composition. As such, bones of archaeological interest or ivory pieces (known as ecofacts) were included in the literature review, although their present composition is mostly represented by the mineral phase.

Table 3. Application of inorganic nanomaterials for the treatment of other types of cultural heritage of an organic nature (references presented in chronological order).

\begin{tabular}{|c|c|c|c|c|}
\hline Artifact Type & $\begin{array}{l}\text { Nanomaterial } \\
\text { Characteristics }\end{array}$ & Application Method & Obtained Results & References \\
\hline $\begin{array}{c}\text { Pre-Columbian } \\
\text { archaeological textiles }\end{array}$ & $\begin{array}{l}\text { AgNPs, } 10-15 \mathrm{~nm} \text { and } \\
50-80 \mathrm{~nm}\end{array}$ & $\begin{array}{l}\text { Applied using a patented } \\
\text { method to a concentration } \\
\text { of } 4.5 \mathrm{ppm} / \mathrm{g} \text { of } \\
\text { textile/disinfection cycle }\end{array}$ & $\begin{array}{l}\text { Application of AgNPs led to the } \\
\text { protection of textiles against } \\
\text { Pseudomonas aeruginosa (by } \\
\text { 63-97\%, depending on the strain } \\
\text { and exposition time). }\end{array}$ & [72] \\
\hline $\begin{array}{l}\text { Historical leather } \\
\text { (XVIIIth century) }\end{array}$ & $\begin{array}{l}\mathrm{Ca}(\mathrm{OH})_{2} \text {, solvothermal } \\
\text { method, hexagonal } \\
\text { platelets, 20-30 nm } \\
\text { (thickness) }\end{array}$ & $\begin{array}{c}\text { Mixed with calcium lactate } \\
\text { nanoparticles, applied by } \\
\text { dipping on real and } \\
\text { historical leather }\end{array}$ & $\begin{array}{l}\text { After treatment application, the } \\
\mathrm{pH} \text { of the historical leather was } \\
\text { adjusted to } 4.5 \text { with no } \\
\text { detrimental effect on } \\
\text { the collagen. }\end{array}$ & [73] \\
\hline $\begin{array}{c}\text { Pre-Columbian } \\
\text { archaeological textiles }\end{array}$ & AgNPs $(10-80 \mathrm{~nm})$ & $\begin{array}{l}\text { Misting disinfection using } \\
\text { patented installation }\end{array}$ & $\begin{array}{l}\text { The treatment led to a reduction } \\
\text { in microbial contamination by } \\
30.8-99.9 \% \text { (depending on the } \\
\text { microbial species and initial } \\
\text { level of contamination) for } \\
\text { several microbial lines (most } \\
\text { resistant-Bacillus spp.; more } \\
\text { sensitive-Oceanobacillus, } \\
\text { Kocuria, Paracoccus, Cladosporium, } \\
\text { and Penicillium spp.) No changes } \\
\text { were recorded in the pH values } \\
\text { and esthetic characteristics of the } \\
\text { treated samples. }\end{array}$ & [74] \\
\hline $\begin{array}{l}\text { Linen fabric samples } \\
\text { (simulating old } \\
\text { stained samples) }\end{array}$ & $\begin{array}{c}\mathrm{TiO}_{2}, \mathrm{ZnO}, \\
\text { 3-18 nm, commercial }\end{array}$ & $\begin{array}{l}\text { Spraying the simulated old } \\
\text { stained samples }\end{array}$ & $\begin{array}{l}\mathrm{TiO}_{2} \text { treatment led to higher } \\
\text { fading of the stains, compared } \\
\text { with } \mathrm{ZnO} ; \mathrm{TiO}_{2} \text { had higher } \\
\text { hydrophobicity than } \\
\mathrm{ZnO} \text {. Due to the fact of safety } \\
\text { reasons, to protect the artifacts, } \\
\text { the authors suggest the use of } \\
\mathrm{ZnO} \text { as self-cleaning agent. }\end{array}$ & [75] \\
\hline $\begin{array}{l}\text { Cotton exposed to } \\
\text { fungi commonly found } \\
\text { on ancient textiles }\end{array}$ & $\begin{array}{c}\text { Wollastonite }\left(\mathrm{CaSiO}_{3}\right) \\
\text { nanofibers, } \\
\text { 30-110 nm, commercial }\end{array}$ & $\begin{array}{l}\text { Immersion of cotton strips } \\
\text { in nanomaterial gel }(20 \%)\end{array}$ & $\begin{array}{l}\text { Impregnation led to significant } \\
\text { limitation of } A \text {. niger activity on } \\
\text { cotton as demonstrated by the } \\
\text { tensile tests. }\end{array}$ & [76] \\
\hline $\begin{array}{l}\text { Ivory (from ancient } \\
\text { elephant tusks) }\end{array}$ & $\begin{array}{l}\text { Hydroxyapatite (HAP): } \\
\text { spherical, } 50 \mathrm{~nm}, \\
\text { hydrothermal method }\end{array}$ & $\begin{array}{l}\text { Immersion in the colloidal } \\
\text { solution, dried }\end{array}$ & $\begin{array}{l}\text { After treatment, an HAP layer } \\
\text { formed (protecting the ivory } \\
\text { from further deterioration), } \\
\text { repairing the loose and porous } \\
\text { surface. Hardness, elastic } \\
\text { modulus, and anti-scratch } \\
\text { performance were significantly } \\
\text { improved. No esthetic changes } \\
\text { were recorded. }\end{array}$ & [77] \\
\hline
\end{tabular}


Table 3. Cont.

\begin{tabular}{|c|c|c|c|c|}
\hline Artifact Type & $\begin{array}{l}\text { Nanomaterial } \\
\text { Characteristics }\end{array}$ & Application Method & Obtained Results & References \\
\hline $\begin{array}{l}\text { Archaeological human } \\
\text { bone remains, Iron age }\end{array}$ & $\begin{array}{c}\mathrm{Ca}(\mathrm{OH})_{2} \text { nanoparticles } \\
\text { dispersed in 2-propanol } \\
\text { and diammonium } \\
\text { hydrogen } \\
\text { phosphate (DAP) }\end{array}$ & $\begin{array}{c}\text { Bones soaked for in } \\
\mathrm{Ca}(\mathrm{OH})_{2} \text {, dried, soaked } \\
\text { in DAP }\end{array}$ & $\begin{array}{l}\text { In situ synthesis of hydroxyapatite, } \\
\text { led to an increase in hardness (up } \\
\text { to } 56 \% \text { ) and mineral density, and } \\
\text { there was a significant reduction in } \\
\text { pore volume and surface area. No } \\
\text { substantial effect on the ability to } \\
\text { recover endogenous DNA } \\
\text { molecules was recorded. }\end{array}$ & [78] \\
\hline $\begin{array}{l}\text { Iron tannate } \\
\text { dyed cotton }\end{array}$ & $\begin{array}{l}\mathrm{CaCO}_{3}(90 \mathrm{~nm}), \mathrm{SiO}_{2} \\
\text { (spherical, } 35 \mathrm{~nm}) \text {, in } \\
\text { diverse complex } \\
\text { combination with } \\
\text { polyethyleneimine, car- } \\
\text { boxymethylcellulose, } \\
\text { cellulose nanofibers, or } \\
\text { polyvinylpyrrolidone }\end{array}$ & $\begin{array}{l}\text { Nebulization/brush } \\
\text { application on } \\
\text { naturally and } \\
\text { accelerated } \\
\text { aged samples }\end{array}$ & $\begin{array}{c}\mathrm{SiO}_{2} \text { nanoparticles, in combination } \\
\text { with } \\
\text { Nanocellulose, stabilized the } \\
\text { naturally aged samples, while } \\
\text { calcium carbonate nanoparticles } \\
\text { were used as deacidification } \\
\text { treatment (pH changed from } 3.6 \text { to } \\
\text { 7.5). CaCO } 3 \text { also protected } \\
\text { strengthening agents, which led to } \\
\text { an increase in the mechanical } \\
\text { properties of the samples; after } \\
\text { artificial aging, the deacidified } \\
\text { samples revealed a slowing down } \\
\text { of cotton degradation. }\end{array}$ & [79] \\
\hline Pterosaur fossils & $\begin{array}{l}\mathrm{Ca}(\mathrm{OH})_{2} \text { (hexagonal, } \\
20 \mathrm{~nm}) / \text { kaolin } \\
\text { (nanosheets, } 4-12 \mathrm{~nm} \\
\text { thickness) } \\
\text { nanocomposite, } \\
\text { dispersed in ethanol }\end{array}$ & $\begin{array}{l}\text { Brush application } \\
\text { to saturation }\end{array}$ & $\begin{array}{l}\text { The treatment had no significant } \\
\text { effect on the breathability of the } \\
\text { fossil, significantly enhanced the } \\
\text { consolidation strength of } \\
\text { the fossil, porosity was reduced to } \\
51 \% \text {; no eye-detected effects on the } \\
\text { color of the fossil. }\end{array}$ & [80] \\
\hline $\begin{array}{l}\text { Parchment from } \\
\text { goat skin }\end{array}$ & $\begin{array}{c}\text { Tea leaf-mediated } \\
\text { AgNPs, spherical, oval, } \\
\text { and hexagonal shapes, } \\
\quad 20-50 \mathrm{~nm}\end{array}$ & $\begin{array}{l}\text { Deposited on } \\
\text { parchment samples, } \\
\text { artificially aged }\end{array}$ & $\begin{array}{l}\text { Antimicrobial treatment effective } \\
\text { against bacteria and fungi } \\
\text { (Streptomyces } \\
\text { Albidoflavus, Cladosporium } \\
\text { xanthochromaticum, } \text { A. fumigatus, } \\
\text { Byssochlamys spectabilis) at a } 0.025 \% \\
\text { concentration. The treatment did } \\
\text { not significantly influence the } \\
\text { chemical and mechanical } \\
\text { characteristics of treated } \\
\text { parchment even after accelerated } \\
\text { thermal aging. }\end{array}$ & [81] \\
\hline $\begin{array}{c}\text { Simulated } \\
\text { bone artifacts }\end{array}$ & $\begin{array}{c}\mathrm{Ca}(\mathrm{OH})_{2}, 217 \mathrm{~nm}, \\
\text { dispersed in 2-propanol }\end{array}$ & $\begin{array}{l}\text { In situ growth of } \\
\mathrm{Ca}\left(\mathrm{SO}_{4}\right)_{2} \text { by the drip- } \\
\text { permeance method }\end{array}$ & $\begin{array}{l}\mathrm{A} \mathrm{Ca}\left(\mathrm{SO}_{4}\right)_{2} \cdot 2 \mathrm{H}_{2} \mathrm{O} \text { continuous } \\
\text { phase formed in situ which filled } \\
\text { the holes, bridged } \\
\text { the cracks, and conferred strength } \\
\text { to the bones, maintaining their } \\
\text { original appearance. } \\
\text { Microhardness increased by } 3 \\
\text { times, porosity reduced by } 10 \% \text {, } \\
\text { and the color difference by } 2.7 \text {. }\end{array}$ & [82] \\
\hline
\end{tabular}

As can be observed from Table 3, inorganic nanomaterials also find application in the protection of diverse cultural heritage artifacts such as dinosaur fossils, ivory, archaeological bones, leather bindings, parchment, or textiles. The consolidation application is correlated with the use of calcium-based nanomaterials (either calcium hydroxide or 
hydroxyapatite), as bone-type artifacts (ivory, bones, horns, antlers, etc.) have as a major inorganic constituent calcium phosphate. As such, their consolidation can be attempted using similar materials. Starting from these considerations, the in situ formation or the deposition of hydroxyapatite nanoparticles on artifacts with a high hydroxyapatite content represents an appropriate strategy. The materials are not only compatible with the inorganic component of the artifacts but are also able to fill the voids that appeared as a result of organic fraction destruction, increasing the mechanical properties of the treated artifacts and, consequently, their resistance. More than that, the application of the treatment does not negatively influence the possibility of recovering endogenous DNA molecules from the archaeological material [78].

Similar to the paper and wood applications, the deacidification of leather or dyed textiles can be achieved using similar compounds. The literature reviewed presented some examples on this topic, suggesting the application of calcium hydroxide or carbonate for deacidification purposes [73,79]. Their action on such artifacts is similar with the previously presented application, and particular attention is necessary for the interaction of the deacidification agent-collagen in the case of leather artifacts.

The final application identified in the literature, antimicrobial protection, is surprisingly underrepresented. Silver is a well-known antimicrobial agent, and its application was to be expected. However, the lack of studies regarding other well-known antimicrobial nanomaterials (such as copper nanoparticles, copper oxide, and zinc oxide) is equally surprising. The evaluation of phytosynthesized silver nanoparticles for the antimicrobial protection of parchment is remarkable [81]; however, in our opinion, this approach is highly underexplored. Their use could eliminate some of the risks associated with the application of silver nanoparticles including the risk of inducing esthetic alterations.
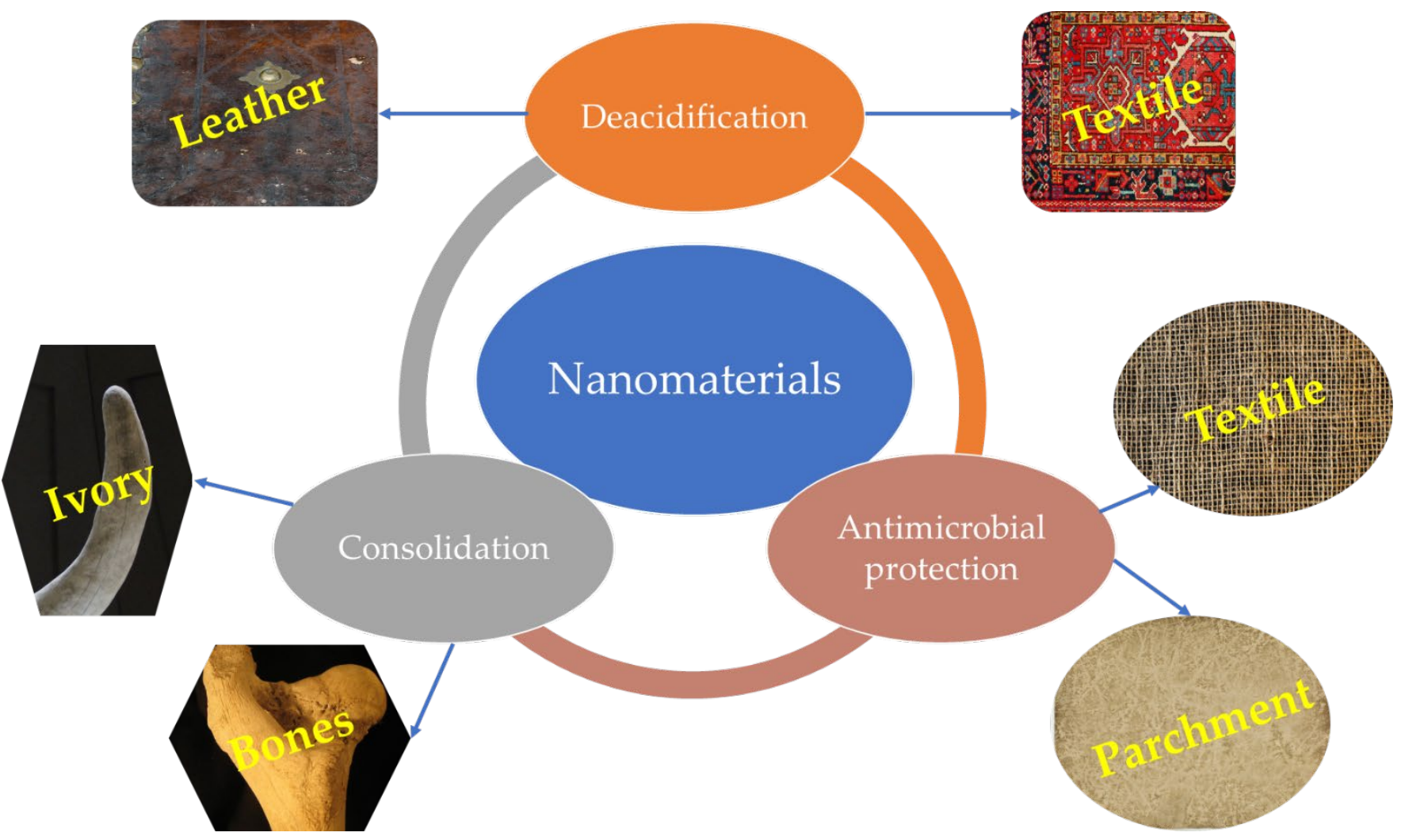

Figure 5. Examples of the nanomaterials' applications in the conservation of other types of artifacts.

\section{Conclusions and Future Perspectives}

As a conclusion to the presented studies, inorganic nanomaterials represent a viable approach for the restoration and conservation of several types of cultural heritage artifacts 
of organic nature including paper, wood, papyrus, parchment, bone-type materials, leather, and textiles.

The application of nanomaterials can be divided in three main categories:

- $\quad$ Enhancement/protection of mechanical and esthetic characteristics;

- $\quad$ Protection from acid or UV-induced degradation ( $\mathrm{pH}$ regulation, UV adsorption);

- Antimicrobial protection.

The selection of the materials for all these applications requires extensive studies before being possible to propose them at an industrial scale. Among the well-established applications, such as deacidification using calcium oxide or hydroxide, the potential improvements are related to the nanoparticles' dimensions, which could influence the results of their application. Antimicrobial protection represents, in our opinion, the area with the most possibilities for improvement. For example, there could be studied other metallic or metal oxides nanoparticles phytosynthesized, a synthesis method which could enhance their properties and, at the same time, provide the appropriate manipulation of NP morphology [83]. Another prospective application is represented by nanomaterials with a double role. For example, calcium-substituted hydroxyapatite could be applied for the consolidation of artifacts, while an appropriate selection of the metal used for substitution (i.e., $\mathrm{Zn}, \mathrm{Co}$, or Ag) could also provide antimicrobial potential [84].

The main goal of cultural heritage protection should be the preservation of the artifacts in a state as close as possible to their original form as well as to offer the possibility to reverse the treatment, if necessary. Although promising, the application of nanomaterials for the protection of cultural heritage should be subjected to thorough tests in order to ensure that no detrimental effect is induced by the treatment, either mechanically or to the esthetic properties. Finally, another aspect that should be clarified in future studies is the possibility of establishing reversible treatments using nanomaterials, one of the major requests when discussing the protection of cultural heritage artifacts.

Author Contributions: Conceptualization, T.F., I.F. and R.C.F.; methodology, R.C.F.; data collection, T.F.; validation, I.F. and R.C.F.; writing-original draft preparation, R.C.F. and I.F.; writing-review and editing, R.C.F. and I.F.; supervision, R.C.F.; project administration, R.C.F.; funding acquisition, R.C.F. All authors have read and agreed to the published version of the manuscript.

Funding: This work was supported by the Romanian Ministry of Research and Innovation, MCI, (Ministry of Research, Innovation, and Digitization, MCID) through the INCDCP ICECHIM Bucharest 2019-2022 Core Program PN. 19.23-Chem-Ergent (Project No. 19.23.03). The authors gratefully acknowledge the support obtained by a grant from the Romanian National Authority for Scientific Research and Innovation, CCCDI-UEFISCDI (Project No. PN-III-P2-2.1-PTE-2019-0579, Contract: 61PTE/2020) within PNCDI III. The APC was funded by the INCDCP ICECHIM Bucharest 2019-2022 Core Program. PN. 19.23-Chem-Ergent, (Project No. 19.23.03).

Data Availability Statement: Not applicable.

Conflicts of Interest: The authors declare no conflict of interest.

\section{References}

1. Mcintyre-Tamwoy, S. The Impact of Global Climate Change and Cultural Heritage: Grasping the Issues and Defining the Problem. Hist. Environ. 2008, 21, 1-9.

2. $\quad$ Bayda, S.; Adeel, M.; Tuccinardi, T.; Cordani, M.; Rizzolio, F. The History of Nanoscience and Nanotechnology: From ChemicalPhysical Applications to Nanomedicine. Molecules 2020, 25, 112. [CrossRef] [PubMed]

3. Guo, D.; Xie, G.; Luo, J. Mechanical Properties of Nanoparticles: Basics and Applications. J. Phys. D Appl. Phys. $2013,47,013001$. [CrossRef]

4. Buzea, C.; Pacheco, I. Nanomaterials and Their Classification. Adv. Struct. Mat. 2017, 62, 3-45. [CrossRef]

5. Serafini, I.; Ciccola, A. Nanotechnologies and Nanomaterials: An Overview for Cultural Heritage. In Nanotechnologies and Nanomaterials for Diagnostic, Conservation and Restoration of Cultural Heritage; Lazzara, G., Fakhrullin, R., Eds.; Elsevier: Amsterdam, The Netherlands, 2019; pp. 325-380. [CrossRef]

6. Zhu, J.; Zhang, P.; Ding, J.; Dong, Y.; Cao, Y.; Dong, W.; Zhao, X.; Li, X.; Camaiti, M. Nano Ca(OH)2: A review on synthesis, properties and applications. J. Cult. Herit. 2021, 50, 25-42. [CrossRef] 
7. Walsh-Korbs, Z.; Avérous, L. Recent developments in the conservation of materials properties of historical wood. Progr. Mat. Sci. 2019, 102, 167-221. [CrossRef]

8. Girginova, P.I.; Galacho, C.; Veiga, R.; Santos Silva, A.; Candeias, A. Inorganic Nanomaterials for Restoration of Cultural Heritage: Synthesis Approaches towards Nanoconsolidants for Stone and Wall Paintings. ChemSusChem 2018, 11, 4168-4182. [CrossRef]

9. Ricca, M.; La Russa, M.F. Challenges for the protection of underwater cultural heritage (UCH), from waterlogged and weathered stone materials to conservation strategies: An overview. Heritage 2020, 3, 402-411. [CrossRef]

10. Franco-Castillo, I.; Hierro, L.; de la Fuente, J.M.; Seral-Ascaso, A.; Mitchell, S.G. Perspectives for antimicrobial nanomaterials in cultural heritage conservation. Chem 2021, 7, 629-669. [CrossRef]

11. Dahlin, E. Damage assessment-causes, mechanisms and measurements. In Proceedings of the 5th EC Conference Cultural Heritage Research: A Pan-European Challenge, Cracow, Poland, 16-18 May 2002; Institute of Catalysis and Surface Chemistry: Cracow, Poland, 2003; pp. 57-60.

12. Fabbri, K.; Bonora, A. Two New Indices for Preventive Conservation of the Cultural Heritage: Predicted Risk of Damage and Heritage Microclimate Risk. J. Cult. Herit. 2021, 47, 208-217. [CrossRef]

13. Baxter, M. Artifact Classification: A Conceptual and Methodological Approach, by Dwight W. Read, 2007. Walnut Creek (CA): Left Coast Press; ISBN 978-1-59874-102-5 Hardback £30 \& US\$89; 363 Pp., 61 Figs., 31 Tables. Cambridge Archaeol. J. 2009, 19, 260-261. [CrossRef]

14. Pyzik, A.; Ciuchcinski, K.; Dziurzynski, M.; Dziewit, L. The Bad and the Good-Microorganisms in Cultural Heritage Environments-An Update on Biodeterioration and Biotreatment Approaches. Materials 2021, 14, 177. [CrossRef] [PubMed]

15. Sterflinger, K.; Piñar, G. Microbial deterioration of cultural heritage and works of art-tilting at windmills? Appl. Microbiol. Biotechnol. 2013, 97, 9637-9646. [CrossRef]

16. Blanchette, R.A.; Nilsson, T.; Daniel, G.; Abad, A. Biological Degradation of Wood Author. In Archaeological Wood Properties, Chemistry, and Preservation; Rowell, R.M., Barbour, R.J., Eds.; American Chemical Society: Washington, DC, USA, 1990; pp. 141-174.

17. Gjelstrup Björdal, G. Microbial degradation of waterlogged archaeological wood. J. Cult. Herit. 2012, 13, S118-S122. [CrossRef]

18. Gutarowska, B.; Pietrzak, K.; Machnowski, W.; Milczarek, J.M. Historical textiles - a review of microbial deterioration analysis and disinfection methods. Textile Res. J. 2016, 87, 2388-2406. [CrossRef]

19. Boyatzis, S.C.; Velivasaki, G.; Malea, E. A study of the deterioration of aged parchment marked with laboratory iron gall inks using FTIR-ATR spectroscopy and micro hot table. Herit. Sci. 2016, 4, 13. [CrossRef]

20. Dolgin, B.; Bulatov, V.; Schechter, I. Non-destructive assessment of parchment deterioration by optical methods. Anal. Bioanal. Chem. 2007, 388, 1885-1896. [CrossRef]

21. Doménech-Carbó, M.T.; Buendía-Ortuño, M.; Pasies-Oviedo, T.; Osete-Cortina, L. Analytical study of waterlogged ivory from the Bajo de la campana site (Murcia, Spain). Microchem. J. 2016, 126, 381-405. [CrossRef]

22. Matthiesen, H.; Høier Eriksen, A.M.; Hollesen, J.; Collins, M. Bone degradation at five Arctic archaeological sites: Quantifying the importance of burial environment and bone characteristics. J. Archaeol. Sci. 2021, 125, 105296. [CrossRef]

23. Baglioni, P.; Chelazzi, D.; Giorgi, R. Deacidification of Paper, Canvas and Wood. In Nanotechnologies in the Conservation of Cultural Heritage; Springer: Berlin, Germany, 2015; pp. 117-144. [CrossRef]

24. Wójciak, A. Deacidification of Paper with $\mathrm{Mg}(\mathrm{OH})_{2}$ Nanoparticles: The Impact of Dosage on Process Effectiveness. Wood Res. 2016, 61, 937-950.

25. Poggi, G.; Sistach, M.C.; Marin, E.; Garcia, J.F.; Giorgi, R.; Baglioni, P. Calcium Hydroxide Nanoparticles in Hydroalcoholic Gelatin Solutions (GeolNan) for the Deacidification and Strengthening of Papers Containing Iron Gall Ink. J. Cul. Herit. 2016, 18, 250-257. [CrossRef]

26. Afsharpour, M.; Imani, S. Preventive Protection of Paper Works by Using Nanocomposite Coating of Zinc Oxide. J. Cult. Herit. 2017, 25, 142-148. [CrossRef]

27. Poggi, G.; Giorgi, R.; Mirabile, A.; Xing, H.; Baglioni, P. A Stabilizer-Free Non-Polar Dispersion for the Deacidification of Contemporary Art on Paper. J. Cult. Herit. 2017, 26, 44-52. [CrossRef]

28. Bastone, S.; Chillura Martino, D.F.; Renda, V.; Saladino, M.L.; Poggi, G.; Caponetti, E. Alcoholic Nanolime Dispersion Obtained by the Insolubilisation-Precipitation Method and Its Application for the Deacidification of Ancient Paper. Colloids Surf. A 2017, 513, 241-249. [CrossRef]

29. Rushdy, A.M.; Wahba, W.N.; Abd-Aziz, M.S.; El Samahy, M.; Kamel, S. A Comparative Study of Consolidation Materials for Paper Conservation. Int. J. Conserv. Sci. 2017, 8, 441-452.

30. Ariafar, A.A.; Afsharpour, M.; Samanian, K. Use of $\mathrm{TiO}_{2} /$ Chitosan Nanoparticles for Enhancing the Preservative Effects of Carboxymethyl Cellulose in Paper-Art-Works against Biodeterioration. Int. Biodeter. Biodegrad. 2018, 131, 67-77. [CrossRef]

31. Huang, J.; Liang, G.; Lu, G.; Zhang, J. Conservation of Acidic Papers Using a Dispersion of Oleic Acid-Modified MgO Nanoparticles in a Non-Polar Solvent. J. Cult. Herit. 2018, 34, 61-68. [CrossRef]

32. Amornkitbamrung, L.; Marnul, M.C.; Palani, T.; Hribernik, S.; Kovalcik, A.; Kargl, R.; Stana-Kleinschek, K.; Mohan, T. Strengthening of Paper by Treatment with a Suspension of Alkaline Nanoparticles Stabilized by Trimethylsilyl Cellulose. Nano-Struct. Nano-Objects 2018, 16, 363-370. [CrossRef]

33. Saoud, K.M.; Saeed, S.; al Soubaihi, R.; Samara, A.; Ibala, I.; el Ladki, D.; Ezzeldeen, O. Application of $\mathrm{Mg}(\mathrm{OH})_{2} \mathrm{Nanosheets} \mathrm{for}$ Conservation and Restoration of Precious Documents and Cultural Archives. BioResources 2018, 13, 3259-3274. [CrossRef] 
34. Hassan, R.R.A.; Mohamed, W.S. The Impact of Methyl Methacrylate Hydroxyethyl Methacrylate Loaded with Silver Nanoparticles on Mechanical Properties of Paper. Appl. Phys. A 2018, 124, 551. [CrossRef]

35. Jia, M.; Zhang, X.; Weng, J.; Zhang, J.; Zhang, M. Protective Coating of Paper Works: ZnO/Cellulose Nanocrystal Composites and Analytical Characterization. J. Cult. Herit. 2019, 38, 64-74. [CrossRef]

36. Fouda, A.; Abdel-Maksoud, G.; Abdel-Rahman, M.A.; Eid, A.M.; Barghoth, M.G.; El-Sadany, M.A.H. Monitoring the Effect of Biosynthesized Nanoparticles against Biodeterioration of Cellulose-Based Materials by Aspergillus Niger. Cellulose 2019, 26, 6583-6597. [CrossRef]

37. Franco Castillo, I.; Garciá Guillén, E.; de la Fuente, J.M.; Silva, F.; Mitchell, S.G. Preventing Fungal Growth on Heritage Paper with Antifungal and Cellulase Inhibiting Magnesium Oxide Nanoparticles. J. Mat. Chem. B 2019, 7, 6412-6419. [CrossRef]

38. Fouda, A.; Abdel-Maksoud, G.; Abdel-Rahman, M.A.; Salem, S.S.; Hassan, S.E.D.; El-Sadany, M.A.H. Eco-Friendly Approach Utilizing Green Synthesized Nanoparticles for Paper Conservation against Microbes Involved in Biodeterioration of Archaeological Manuscript. Int. Biodeter. Biodegrad. 2019, 142, 160-169. [CrossRef]

39. He, B.; Lin, Q.; Chang, M.; Liu, C.; Fan, H.; Ren, J. A New and Highly Efficient Conservation Treatment for Deacidification and Strengthening of Aging Paper by In-Situ Quaternization. Carbohydr. Polym. 2019, 209, 250-257. [CrossRef]

40. Nemoykina, A.L.; Shabalina, A.V.; Svetlichnyi, V.A. Restoration and Conservation of Old Low-Quality Book Paper Using Aqueous Colloids of Magnesium Oxyhydroxide Obtained by Pulsed Laser Ablation. J. Cult. Herit. 2019, 39, 42-48. [CrossRef]

41. Weng, J.; Zhang, X.; Jia, M.; Zhang, J. Deacidification of Aged Papers Using Dispersion of $\mathrm{Ca}(\mathrm{OH})_{2}$ Nanoparticles in Subcritical 1,1,1,2-Tetrafluoroethane (R134a). J. Cult. Herit. 2019, 37, 137-147. [CrossRef]

42. Malešič, J.; Kadivec, M.; Kunaver, M.; Skalar, T.; Cigić, I.K. Nano Calcium Carbonate versus Nano Calcium Hydroxide in Alcohols as a Deacidification Medium for Lignocellulosic Paper. Herit. Sci. 2019, 7, 50. [CrossRef]

43. Taghiyari, H.R.; Kalantari, A.; Kalantari, A.; Avramidis, S. Effect of wollastonite nanofibers and exposure to Aspergillus niger fungus on air flow rate in paper. Measurement 2019, 136, 307-313. [CrossRef]

44. Xu, Q.; Poggi, G.; Resta, C.; Baglioni, M.; Baglioni, P. Grafted Nanocellulose and Alkaline Nanoparticles for the Strengthening and Deacidification of Cellulosic Artworks. J. Colloid Interface Sci. 2020, 576, 147-157. [CrossRef]

45. Bergamonti, L.; Potenza, M.; Haghighi Poshtiri, A.; Lorenzi, A.; Sanangelantoni, A.M.; Lazzarini, L.; Lottici, P.P.; Graiff, C. Ag-Functionalized Nanocrystalline Cellulose for Paper Preservation and Strengthening. Carbohydr. Polym. 2020, 231 , 115773. [CrossRef]

46. Fan, H.; Guo, M.; Mou, H.; Shi, W.; Li, J.; Liu, J. Deacidification and Reinforcement of Old Books Using Sodium Carbonate and Latex Composites. Bioresources 2020, 15, 302-316. [CrossRef]

47. Lisuzzo, L.; Cavallaro, G.; Milioto, S.; Lazzara, G. Halloysite Nanotubes Filled with MgO for Paper Reinforcement and Deacidification. Appl. Clay Sci. 2021, 213, 106231. [CrossRef]

48. Zając, I.; Szulc, J.; Gutarowska, B. The Effect of Ethylene Oxide and Silver Nanoparticles on Photographic Models in the Context of Disinfection of Photo Albums. J. Cult. Herit. 2021, 51, 59-70. [CrossRef]

49. Longo, E.; Senapeschi, A.N.; Varela, J.A.; Whittemore, O.J. Mechanisms of Water Interaction with an MgO Surface. Langmuir 1985, 1, 456-461. [CrossRef]

50. Baty, J.W.; Maitland, C.L.; Minter, W.; Hubbe, M.A.; Jordan-Mowery, S.K. Deacidification for the conservation and preservation of paper-based works: A review. Bioresources 2010, 5, 1955-2023. [CrossRef]

51. Hassan, R.R.A.; Mahmoud, S.M.A.; Nessem, M.A.; Aty, R.T.A.; Ramzy, M.G.; Dessoky, E.S.; Abdelkhalek, A.; Salem, M.Z.M. Hydroxypropyl Cellulose Loaded with ZnO Nanoparticles for Enhancing the Mechanical Properties of Papyrus (Cyperus Papyrus L.) Strips. BioResources 2021, 16, 2607-2625. [CrossRef]

52. Zhou, K.; Li, A.; Xie, L.; Wang, C.C.; Wang, P.; Wang, X. Mechanism and Effect of Alkoxysilanes on the Restoration of Decayed Wood Used in Historic Buildings. J. Cult. Herit. 2020, 43, 64-72. [CrossRef]

53. Fierascu, R.C.; Doni, M.; Fierascu, I. Selected Aspects Regarding the Restoration/Conservation of Traditional Wood and Masonry Building Materials: A Short Overview of the Last Decade Findings. Appl. Sci. 2020, 10, 1164. [CrossRef]

54. Poggi, G.; Toccafondi, N.; Chelazzi, D.; Canton, P.; Giorgi, R.; Baglioni, P. Calcium Hydroxide Nanoparticles from Solvothermal Reaction for the Deacidification of Degraded Waterlogged Wood. J. Colloid Interface Sci. 2016, 473, 1-8. [CrossRef]

55. Harandi, D.; Ahmadi, H.; Mohammadi Achachluei, M. Comparison of $\mathrm{TiO}_{2}$ and $\mathrm{ZnO}$ Nanoparticles for the Improvement of Consolidated Wood with Polyvinyl Butyral against White Rot. Int. Biodeter. Biodegrad. 2016, 108, 142-148. [CrossRef]

56. Schofield, E.J.; Sarangi, R.; Mehta, A.; Jones, A.M.; Smith, A.; Mosselmans, J.F.W.; Chadwick, A.V. Strontium Carbonate Nanoparticles for the Surface Treatment of Problematic Sulfur and Iron in Waterlogged Archaeological Wood. J. Cult. Herit. 2016, 18, 306-312. [CrossRef]

57. Terzi, E.; Kartal, S.N.; Yilgor, N.; Rautkari, L.; Yoshimura, T. Role of various nano-particles in prevention of fungal decay, mold growth and termite attack in wood, and their effect on weathering properties and water repellency. Int. Biodeter. Biodegrad. 2016, 107, 77-87. [CrossRef]

58. Andriulo, F.; Braovac, S.; Kutzke, H.; Giorgi, R.; Baglioni, P. Nanotechnologies for the restoration of alum-treated archaeological wood. Appl. Phys. A 2016, 122, 322. [CrossRef]

59. Muhcu, D.; Terzi, E.; Kartal, S.N.; Yoshimura, T. Biological performance, water absorption, and swelling of wood treated with nano-particles combined with the application of Paraloid B72 ${ }^{\circledR}$. J. For. Res. 2017, 28, 381-394. [CrossRef] 
60. Guo, H.; Bachtiar, E.V.; Ribera, J.; Heeb, M.; Schwarze, F.W.M.R.; Burgert, I. Non-biocidal preservation of wood against brown-rot fungi with a $\mathrm{TiO}_{2} / \mathrm{Ce}$ xerogel. Green Chem. 2018, 20, 1375-1382. [CrossRef]

61. Cavallaro, G.; Milioto, S.; Parisi, F.; Lazzara, G. Halloysite Nanotubes Loaded with Calcium Hydroxide: Alkaline Fillers for the Deacidification of Waterlogged Archeological Woods. ACS Appl. Mat. Interfac. 2018, 10, 27355-27364. [CrossRef]

62. Ion, R.M.; Nyokong, T.; Nwahara, N.; Suica-Bunghez, I.R.; Iancu, L.; Teodorescu, S.; Dulama, I.D.; Stirbescu, R.M.; Gheboianu, A.; Grigorescu, R.M. Wood Preservation with Gold Hydroxyapatite System. Herit. Sci. 2018, 6, 37. [CrossRef]

63. De Peres, M.L.; Delucis, R.D.A.; Amico, S.C.; Gatto, D.A. Zinc oxide nanoparticles from microwave-assisted solvothermal process: Photocatalytic performance and use for wood protection against xylophagous fungus. Nanomat. Nanotechnol. 2019, 9, 1-8. [CrossRef]

64. Abbasi, J.; Samanian, K.; Afsharpour, M. Consolidation of Historical Woods Using Polyvinyl Butyral/Zinc Oxide Nano-Composite: Investigation of Water Absorption, Wettability, and Resistance to Weathering. Int. J. Conserv. Sci. 2020, 11, 15-24.

65. Janesch, J.; Czabany, I.; Hansmann, C.; Mautner, A.; Rosenau, T.; Gindl-Altmutter, W. Transparent Layer-by-Layer Coatings Based on Biopolymers and $\mathrm{CeO}_{2}$ to Protect Wood from UV Light. Progr. Org. Coat. 2020, 138, 105409. [CrossRef]

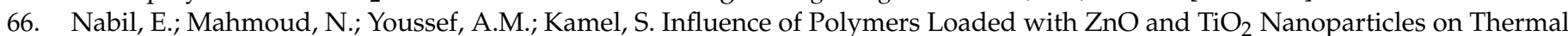
Resistance of Archaeological Wood. Egypt. J. Chem. 2020, 63, 4645-4657. [CrossRef]

67. Taglieri, G.; Daniele, V.; Macera, L.; Schweins, R.; Zorzi, S.; Capron, M.; Chaumat, G.; Mondelli, C. Sustainable Nanotechnologies for Curative and Preventive Wood Deacidification Treatments: An Eco-Friendly and Innovative Approach. Nanomaterials 2020, 10, 1744. [CrossRef] [PubMed]

68. Yves, K.G.; Chen, T.; Aladejana, J.T.; Wu, Z.; Xie, Y. Preparation, Test, and Analysis of a Novel Aluminosilicate-Based Antimildew Agent Applied on the Microporous Structure of Wood. ACS Omega 2020, 5, 8784-8793. [CrossRef]

69. Parisi, F.; Bernardini, F.; Cavallaro, G.; Mancini, L.; Milioto, S.; Prokop, D.; Lazzara, G. Halloysite Nanotubes/Pluronic Nanocomposites for Waterlogged Archeological Wood: Thermal Stability and X-Ray Microtomography. J. Thermal Anal. Calorim. 2020, 141, 981-989. [CrossRef]

70. Lisuzzo, L.; Hueckel, T.; Cavallaro, G.; Sacanna, S.; Lazzara, G. Pickering Emulsions Based on Wax and Halloysite Nanotubes: An Ecofriendly Protocol for the Treatment of Archeological Woods. ACS Appl. Mat. Interfac. 2021, 13, 1651-1661. [CrossRef]

71. Weththimuni, M.L.; Milanese, C.; Licchelli, M.; Malagodi, M. Improving the Protective Properties of Shellac-Based Varnishes by Functionalized Nanoparticles. Coatings 2021, 11, 419. [CrossRef]

72. Pietrzak, K.; Otlewska, A.; Puchalski, M.; Gutarowska, B.; Guiamet, P. Antimicrobial Properties of Silver Nanoparticles against Biofilm Formation by Pseudomonas Aeruginosa on Archaeological Textiles. Appl. Environ. Biotechnol. 2017, 2, 1-9. [CrossRef]

73. Baglioni, M.; Bartoletti, A.; Bozec, L.; Chelazzi, D.; Giorgi, R.; Odlyha, M.; Pianorsi, D.; Poggi, G.; Baglioni, P. Nanomaterials for the Cleaning and PH Adjustment of Vegetable-Tanned Leather. Appl. Phys. A 2016, 122, 1-11. [CrossRef]

74. Pietrzak, K.; Puchalski, M.; Otlewska, A.; Wrzosek, H.; Guiamet, P.; Piotrowska, M.; Gutarowska, B. Microbial Diversity of Pre-Columbian Archaeological Textiles and the Effect of Silver Nanoparticles Misting Disinfection. J. Cult. Herit. 2017, 23, 138-147. [CrossRef]

75. Osman, E.M.; Ibrahim, S.F.; Essa, D.M. Evaluation the Using of Nano Materials as Self Cleaning Agents of Different Kinds of Stained Archeological Textiles. Egypt. J. Chem. 2017, 60, 945-956. [CrossRef]

76. Taghiyari, H.R.; Majidinajafabadi, R.; Vahidzadeh, R. Wollastonite to hinder growth of Aspergillus niger fungus on cotton textile. An. Acad. Bras. Ciênc. 2018, 90, 2797-2804. [CrossRef]

77. Gong, W.; Yang, S.; Zheng, L.; Xiao, H.; Zheng, J.; Wu, B.; Zhou, Z. Consolidating Effect of Hydroxyapatite on the Ancient Ivories from Jinsha Ruins Site: Surface Morphology and Mechanical Properties Study. J. Cult. Herit. 2019, 35, 116-122. [CrossRef]

78. Salvatore, A.; Vai, S.; Caporali, S.; Caramelli, D.; Lari, M.; Carretti, E. Evaluation of Diammonium Hydrogen Phosphate and $\mathrm{Ca}(\mathrm{OH})_{2}$ Nanoparticles for Consolidation of Ancient Bones. J. Cult. Herit. 2020, 41, 1-12. [CrossRef]

79. Palladino, N.; Hacke, M.; Poggi, G.; Nechyporchuk, O.; Kolman, K.; Xu, Q.; Persson, M.; Giorgi, R.; Holmberg, K.; Baglioni, P.; et al. Nanomaterials for Combined Stabilisation and Deacidification of Cellulosic Materials—the Case of Iron-Tannate Dyed Cotton. Nanomaterials 2020, 10, 900. [CrossRef] [PubMed]

80. Zhu, J.; Ding, J.; Zhang, P.; Dong, W.; Zhao, X.; Camaiti, M.; Li, X. In-Situ Growth Synthesis of Nanolime/Kaolin Nanocomposite for Strongly Consolidating Highly Porous Dinosaur Fossil. Constr. Build. Mat. 2021, 300, 124312. [CrossRef]

81. Saada, N.S.; Abdel-Maksoud, G.; Abd El-Aziz, M.S.; Youssef, A.M. Green Synthesis of Silver Nanoparticles, Characterization, and Use for Sustainable Preservation of Historical Parchment against Microbial Biodegradation. Biocatal. Agricult. Biotechnol. 2021, 32, 101948. [CrossRef]

82. Liu, Y.; Hu, Q.; Zhang, K.; Yang, F.; Yang, L.; Wang, L. In-situ growth of calcium sulfate dihydrate as a consolidating material for the archaeological bones. Mat. Lett. 2021, 282, 128713. [CrossRef]

83. Fierascu, I.; Fierascu, I.C.; Brazdis, R.I.; Baroi, A.M.; Fistos, T.; Fierascu, R.C. Phytosynthesized Metallic Nanoparticles-between Nanomedicine and Toxicology. A Brief Review of 2019's Findings. Materials 2020, 13, 574. [CrossRef]

84. Fierascu, I.; Fierascu, R.C.; Somoghi, R.; Ion, R.M.; Moanta, A.; Avramescu, S.M.; Damian, C.M.; Ditu, L.M. Tuned Apatitic Materials: Synthesis, Characterization and Potential Antimicrobial Applications. Appl. Surf. Sci. 2018, 438, 127-135. [CrossRef] 